\title{
A Tribute to Neal Philip Perry Simon 1973-2006
}

\author{
Tony E. Chubbs ${ }^{1}$ and Frank R. Phillips ${ }^{2}$
}

${ }^{1}$ Department of National Defence, 5 Wing Goose Bay, Box 7002, Station A, Happy Valley-Goose Bay, Newfoundland and Labrador A0P 1S0 Canada; e-mail: techubbs@cablelab.net

${ }^{2}$ Department of Natural Resources, Government of Newfoundland and Labrador, Box 175, Station C, Happy Valley-Goose Bay, Newfoundland and Labrador, Newfoundland A0P 1C0 Canada

Chubbs, Tony E., and Frank R. Phillips. 2006. A tribute to Neal Philip Perry Simon, 1973-2006. Canadian Field-Naturalist 121(1): 96-99.

Neal Philip Perry Simon, our friend, hunting companion, and colleague, was born in Labrador City, Newfoundland and Labrador, on Sunday 30 December 1973, to Dave and Doreen Simon. He passed away suddenly and unexpectedly in a tragic accident on 23 September 2006, at the age of 32 near Happy Valley Goose Bay where he resided since 1988. His parents, Dave and Doreen Simon, sister Nicole and fiancée, Leanne Elson, survive him. Neal had a mutual adoration for his grandparents, Carrie and Gordon Templeman, who will miss him dearly.

Neal's early education was in Catholic schools: Notre Dame Academy (primary and elementary) and Labrador City Collegiate (high school) both of which were in Labrador City and have since closed. Neal, along with his grade school pal Colin Carroll, developed a keen interest in biology at an early age, trying his hand at taxidermy in grade seven. Francis Schwab, Neal's first year university professor, was instrumental in introducing him to scientific research, especially the effects of post-fire succession on songbird abundance. His postsecondary education began at Memorial University of Newfoundland in St. John's, Newfoundland and Labrador, where in 1995 he obtained a B.Sc.(Hons) with a major in ecology and evolution and a minor in statistics. It was there, under the instruction of Eric Baggs and the late Dr. Gary Cowen, he was instilled with an appreciation of the importance of small mammals in understanding forest structure dynamics.

In 1996, Neal began his Master of Science in Forestry at the University of New Brunswick under the supervision of Dr. A. W. Diamond. As part of the Atlantic Cooperative Wildlife Ecology Research Network (ACWERN), Neal regularly contributed presentations at the annual workshop from 1998 to 2003. In 2000, Neal continued under the supervision of Dr. Diamond to pursue his Ph.D. on the effects of site productivity and heterogeneity on bird habitat quality and species richness. His research ranged from modelling species distributions to studying the effects of landscape features on habitat use by passerines, with a focus on their demography. Much of Neal's work had an overlying conservation theme linked quite strongly to ecological theory. Neal completed his Ph.D. in 2005 and was about to embark on his post-doctoral research in the spring of 2007.
Neal taught in various capacities at Memorial University of Newfoundland, the University of New Brunswick and St. Mary's University. From 1996 to 1998 , Neal worked as a contract biologist for the College of the North Atlantic in Labrador City and Happy Valley - Goose Bay where he also offered his services as a university tutor in various disciplines, including chemistry and biology. Neal was always there to help out whenever or wherever he could and would always without hesitation say "Yes, just provide me the materials." Students found him friendly and informative and they usually had few problems grasping concepts from him. He will be remembered for his willingness to help, his ability to teach a difficult content area and his friendly personality.

From November 1998, Neal was employed by the Provincial Government of Newfoundland and Labrador, Department of Natural Resources, occupying the position of Regional Ecologist for the Labrador Region. Neal's work concentrated on experimental design, data collection, and analysis of research projects relating to forest management plans in Labrador. Neal's research interests included effects of forest management and changing forest structures and specifically how these changes may affect the spatial and temporal distribution of threatened Woodland Caribou (Rangifer tarandus caribou) in central Labrador. Neal's most recent interests involved sustainable forest management in collaboration with the Government of Newfoundland and Labrador, Department of Natural Resources, and the Université du Québec à Montréal. Neal was about to embark on his post-doctorate research using innovative simulation models to ensure the sustainable management of Labrador's forests while his fiancée and coworker Leanne would be completing her Master of Science in a supporting area of research. Neal was one of those rare ecologists who not only recognize the power of quantitative methods, but also actually understand how to appropriately apply these methods. Having just barely embarked upon his research career, Neal, as attested by his already growing list of publications, was destined for greatness in the world of research and statistics.

Since the summer of 2000, Neal had been an active participant in the North American Breeding Bird Survey (BBS) program and ran the Newfoundland and 


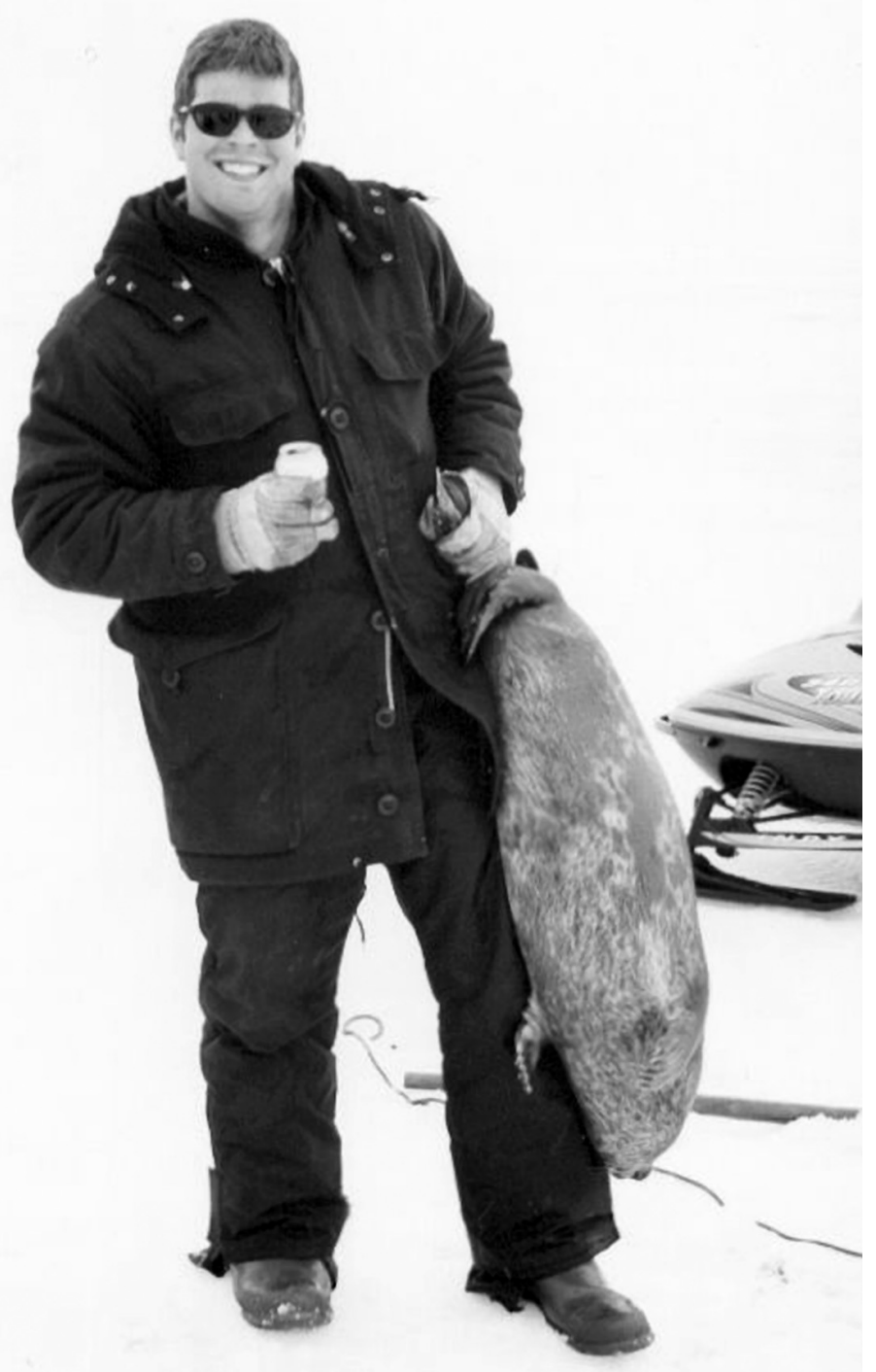

FIGURE 1. Neal P. P. Simon holding his first seal darted off Mulligan Point, 2 May 2003. (Photo courtesy Sarah Townley).

Labrador, Happy Valley - Goose Bay survey route for Environment Canada. Neal was also a committed participant in the Christmas Bird Count (CBC).

Neal was a dedicated member of both the local Squash League and Goose Bay Judo Club. He exemplified the philosophy of Judo in all aspects of his life, striving to maximize his physical, intellectual and personal character by doing his best; and being his best, Neal truly reflected this teaching through his physical strength and fitness, his academic accomplishments and desire to learn. As a competitor, Neal was intense and spirited while always maintaining his youthful grin and sense of humour. Neal's enthusiasm for research in ecology and his jubilant attitude radiated from him, rapidly instilling in his colleagues a source of continual positive motivation. With an acute and intense sense of humour, Neal added a unique and welcome aspect to his interaction with both friends and fellow researchers. As an editor and reviewer of prospective manuscripts, his dedication and support were immeasurable and will be greatly missed.

In 1999, Neal was an original member of the Labrador Wolverine Working Group, and became one of the founding members of the Labrador Woodland Caribou Recovery Team in 2001. Neal was a member of The Society for Conservation Biology, the Wildlife Society, the Atlantic Region of the Canadian Climate Impacts and Adaptation Research Network, the Atlantic Society of Fish and Wildlife Biologists, Atlantic Co-operative Wildlife Ecology Research Network 
(ACWERN), Newfoundland and Labrador Biodiversity working group, Forest Management Planning Team Member for Labrador Districts 19, 20, 21 and 22 and a member of the Institute for Environmental Monitoring and Research - Osprey Technical Committee. Neal was about to join the Groupe de recherche en écologie forestière interuniversitaire at l'Université du Québec à Montréal to complete his post-doctoral research developing habitat and timber harvestingconservation trade-off models for Woodland Caribou.

Neal's interests were varied and included, but were not limited to, modelling species movements, predicting species distributions and understanding the effects of forest management on species occurrence and demography. He spent most summers in Labrador, along with his students and co-workers; in the field conducting songbird point count samples and vegetation plot counts.

We came to know Neal and build a strong friendship when he moved to Happy Valley - Goose Bay in 1998 and shortly thereafer began work as the Ecosystem Ecologist for Labrador. Neal was friendly, energetic and an avid waterfowl and big game hunter. We anxiously awaited mid spring each year when we would travel by snowmobile over the bay ice to Portage Island, Mulligan Point. Here we would participate in the eons old traditional Inuit hunting practice of waiting patiently at breathing holes for Ringed Seals (Pusa hispida). Evenings would be filled with laughter as we swapped humorous exaggerated stories of past good times. Such wonderful times were set against the backdrop of a blazing driftwood fire and the assurance of deep slumber later in our traditional Labrador canvas tents heated with the warmth of woodstoves. Neal often swapped related stories of how he had enjoyed the outdoors with his best hunting buddy, his father Dave, in Western Labrador. It was more important to Neal to enjoy the outdoors than to be successful on a hunt, though more often than not he was. As he so often mentioned to his hunting partner Colin Carroll, "If we don't get anything today, it doesn't matter. Just being here doing this is making my day."

His friends will best remember Neal as a shining, though comedic intellectual, with a love of life and a passion for the outdoors. Through discussions with some of Neal's colleagues and friends in the preparation of this tribute, we have found that Neal existed in several parallel universes, having the same mannerisms, characteristics and sharp wit despite the varied personalities and context of his friends. He will be remembered for his comic additions to his work and conversation slipping easily between extreme seriousness and laughter.

\section{Acknowledgments}

We thank Neal's parents (Dave and Doreen), his sister Nicole, fiancée Leanne, and others for personal information. Colin Carroll, Neal's schoolmate and colleague provided information on Neal's early schooling in Labrador City. We thank Tony Diamond for provid- ing a compilation of Neal's academic achievements. Matt Betts and Joe Nocera provided insight on Neal's life that could only be shared between close colleagues and best friends. Bob Simms shared personal interactions with Neal through their judo club and Bernice Tracy provided details of Neal's association with the College of the North Atlantic. Finally, we would like to thank all of Neal's friends, family, colleagues and acquaintances that contributed to the Neal Simon Memorial Trust to fund an academic scholarship in Neal's honour and memory. Neal appreciated the outdoors and enjoyed hunting and fishing and spending time in the Labrador wilds with Leanne and his dog, Boss. He will be greatly missed by his family, his many friends and his academic colleagues.

\section{Bibliography of Neal P. P. Simon}

Compiled by Tony E. CHubBs

Peer Reviewed Publications:

Elson, L. T., N. P. P. Simon, and D. Kneeshaw. In press. Regeneration differences between fire and clearcut logging in southeastern Labrador: a multiple spatial scale analysis. Canadian Journal of Forest Research: 000-000.

Elson, L. T., and N. P. P. Simon. In press. Plant abundances following clearcutting and stripcutting in central Labrador Northern Journal of Applied Forestry, 00: 000-000.

Elson, L. T., F. E. Schwab, and N. P. P. Simon. In press Winter food habits of willow ptarmigan (Lagopus lagopus) as a mechanism to explain winter sexual segregation. Northeastern Naturalist 00: 000-000.

Roberts, B. A., N. P. P. Simon, and K. W. Deering. In press. The forests and woodlands of Labrador, Canada: Ecology, distribution, and future management. Ecological Research 00: 000-000.

Schwab, F. E., N. P. P. Simon, S. Stryde, and G. Forbes. In press. Effect of post-fire snag removal on breeding birds of western Labrador. Journal of Wildlife Management 00: 000-000.

Schwab, F. E., N. P. P. Simon, and A. R. E. Sinclair. 2006. Breeding birds related to vegetation structure in southeast British Columbia. Journal of Wildlife Management 70: 189-197.

Schwab, F. E., N. P. P. Simon, and S. Nash. 2005. Sex and age segregation of wintering willow ptarmigan in Labrador. Northeastern Naturalist 13: 113-118.

Simon, N. P. P., and F. E. Schwab. 2005. Plant community structure following wildfire in the subarctic forests of Labrador. Northern Journal of Applied Forestry 22: 229-235.

Newbury, T. L., and N. P. P. Simon. 2005. The effects of clearcutting on snowshoe hare (Lepus americanus) relative abundance in central Labrador. Forest Ecology and Management 210: 131-142.

Betts, M., N. P. P. Simon, and J. J. Nocera. 2005. Point count summary statistics differentially predict reproductive activity in bird-habitat relationship studies. Journal of Ornithology 146: 151-159.

Simon, N. P. P., and F. E. Schwab. 2005. The response of conifer and broad-leaved trees and shrubs to wildfire and clearcut logging in the boreal forests of central Labrador. Northern Journal of Applied Forestry 22: 35-41.

Otto, R. D., N. P. P. Simon, S. Couturier, and I. Schmelzer. 2003. Evaluation of satellite collar sample size requirements for mitigation of low-level military jet disturbance 
of the George River caribou herd. Rangifer special issue number 14: 297-302.

Simon, N. P. P., A. W. Diamond, and F. E. Schwab. 2003. Do northern forest bird communities show more ecological plasticity than southern forest bird communities in eastern Canada? Écoscience 10: 298-296.

Simon, N. P. P., F. E. Schwab, and R. D. Otto. 2002. Songbird abundance in clear-cut and burned stands: a comparison of natural disturbance and forest management. Canadian Journal of Forest Research 32: 1343-1350.

Simon, N. P. P., C. B. Stratton, G. J. Forbes, and F. E. Schwab. 2002. Similarity of small mammal abundance in post-fire and clearcut forests. Forest Ecology and Management 165: 163-172.

Schwab, F. E., N. P. P. Simon, and C. G. Carroll. 2001. Breeding songbird abundance in the subarctic forests of western Labrador. Écoscience 8: 1-7.

Schwab, F. E., F. G. Pitoello, and N. P. P. Simon. 2001. Relative palatability of green manure crops and carrots to white-tailed deer. Wildlife Society Bulletin 29: 317-321.

LeCoure, M. I., F. E. Schwab, N. P. P. Simon, and A. W. Diamond. 2000. Effects of post-fire salvage logging on breeding birds in western Labrador. Northeast Wildlife 55: $39-46$.

Simon, N. P. P., F. E. Schwab, and A. W. Diamond. 2000. Patterns of bird abundance in relation to logging in western Labrador. Canadian Journal of Forest Research 30: 257-263.

Simon, N. P. P., F. E. Schwab, M. I. LeCoure, F. R. Phillips, and P. G. Trimper. 1999. Effects of trapper access on marten population in central Labrador. Northeast Wildlife 54: 73-76.

Simon, N. P. P., F. E. Schwab, M. I. LeCoure, and F. R. Phillips. 1999. Fall and winter diet of Martens, Martes americana, in central Labrador related to small mammal densities. Canadian Field-Naturalist 113: 678-680.

Simon, N. P. P., F. E., Schwab, E. M. Baggs, and G. I. McT. Cowan. 1998. Distribution of small mammals among successional and mature forest types in western Labrador. Canadian Field-Naturalist 112: 441-445.

Peer Reviewed Manuscripts in Preparation:

Newbury, T. L., N. P. P. Simon. Moose (Alces alces) browse use in central Labrador Submitted to Canadian Field-Naturalist.

Simon, N. P. P., and A. W. Diamond. Songbird habitat quality across a timber productivity gradient within an unfragmented northern boreal forest: local and landscape effects. Submitted to Landscape Ecology.

Simon, N. P. P., and A. W. Diamond. Evaluation of environmental factors influencing vegetation structure in mature Picea mariana forests using constrained ordination and constrained classification. Submitted to Canadian Journal of Forest Research.

Simon, N. P. P., F. E. Schwab, and J. K. Colbert. Vegetation response to summer and winter logging of Black Spruce Picea mariana forests in central Labrador. Submitted to Northern Journal of Applied Forestry.

Theses:

Simon, N. P. P. 1996. The effects of secondary succession on vegetation structure and its effects on small mammal biodiversity in western Labrador. B.Sc. Honours thesis. Memorial University of Newfoundland, St. John's, Newfoundland and Labrador.
Simon, N. P. P. 1998. Patterns of bird abundance in relation to logging in western Labrador. M.Sc. University of New Brunswick, Fredericton, New Brunswick. 83 pages.

Simon, N. P. P. 2006. The effects of site productivity and heterogeneity on bird habitat quality and species richness. $\mathrm{Ph} . \mathrm{D}$. thesis. University of New Brunswick, Fredericton, New Brunswick. 184 pages.

\section{Reports:}

Schmelzer, I., J. Brazil, T. Chubbs, S. French, S. B. Hearn, R. Jeffery, L. LeDrew, H. Martin, A. McNeill, R. Otto, F. Phillips, G. Mitchell, G. Pittman, N. Simon, and G. Yetman. 2004. Recovery Strategy for three Woodland caribou herds (Rangifer tarandus caribou; Boreal population) in Labrador, Canada. Department of Environment and Conservation, Government of Newfoundland and Labrador, Corner Brook. 51 pages.

Simon, N. P. P. 2003. A summary of some effects of full tree logging - literature review. Internal report - Department of Forest Resources and Agrifoods, Wildlife Division.

Simon, N. P. P., E. Baggs, and G. I. McT. Cowan. 1998. the effect of forest fire on small mammals in western Labrador. Internal report - Department of Forest Resources and Agrifoods, Wildlife Division. 23 pages.

Simon, N. P. P., F. E. Schwab, and M. I. LeCoure. 1998. Labrador marten demographics as determined by winter diet and trapper access. Interim report submitted to the Newfoundland and Labrador Department of Forest Resources and Agrifoods, Wildlife Division.

Simon, N. P. P., F. E. Schwab, and A. W. Diamond. 1998. Patterns of bird abundance in relation to logging in western Labrador. Interim report submitted to: Wildlife Habitat Canada, Newfoundland and Labrador Department of Forest Resources and Agrifoods, Wildlife Division.

Simon, N. P. P., F. E. Schwab, and A. W. Diamond. 1997 The effects of logging on breeding birds in western Labrador. Interim report submitted to: Wildlife Habitat Canada, Newfoundland and Labrador Department of Natural Resources and Wildlife Division.

Workshop and Conference Presentations:

Simon, N. P. P. 2003. Evaluating the effects of landscape change on abundance, productivity, and survival of forest birds (presented with M. Betts). ACWERN, Wolfville, Nova Scotia.

Simon, N. P. P. 2003. Natural disturbance and forest management. Workshop on Natural Disturbance Management. Sustainable Forest Management Network, Corner Brook, Newfoundland and Labrador.

Simon, N. P. P. 2002. The relationship between forest productivity and songbird habitat quality. ACWERN, Rocky Harbour, Newfoundland and Labrador.

Simon, N. P. P. 2000. Songbird abundance and fecundity in relation to forest structure and productivity. ACWERN, St. Andrews, New Brunswick.

Simon, N. P. P. 1998. Patterns of bird abundance in relation to logging in western Labrador/Bird plasticity in relation to latitude. Institute of Environmental Monitoring and Research Seminar Series - Happy Valley - Goose Bay, Newfoundland and Labrador.

Simon, N. P. P. 1997. The effects of logging on birds in western Labrador. ASWFB/ACWERN conference - Alma, New Brunswick.

Simon, N. P. P. 1996. The effects of logging on birds in western Labrador. ACWERN, Bon Portage Island, Nova Scotia. 